\title{
Knowledge, Attitudes, Practices and Information Needs During the COVID-19 Pandemic in Indonesia
}

This article was published in the following Dove Press journal: Risk Management and Healthcare Policy

Sulistyawati Sulistyawati (D) Rokhmayanti Rokhmayanti' Budi Aji ${ }^{2}$

Siwi Pramatama Mars Wijayanti ${ }^{2}$

Siti Kurnia Widi Hastuti'

Tri Wahyuni Sukesi (iD

Surahma Asti Mulasari'

'Department of Public Health, Universitas Ahmad Dahlan, Yogyakarta 55164, Indonesia; ${ }^{2}$ Department of Public Health, Faculty of Health Sciences, Jenderal Soedirman University, Purwokerto 53122, Indonesia
Correspondence: Sulistyawati Sulistyawati Department of Public Health, Universitas Ahmad Dahlan, Jl. Prof Dr Soepomo, Janturan, Umbulharjo, Yogyakarta 55I64, Indonesia

Tel +628170402693

Email sulistyawati.suyanto@ikm.uad.ac.id
Introduction: In the absence of vaccines and specific drugs, prevention effort has been attributed as the primary control mechanism of COVID-19. Knowledge, attitude, and practice are used to determine the current situation and formulate appropriate control interventions as well as risk communication. This study, therefore, aims to assess knowledge, attitude, practice and information needs about COVID-19 in Indonesian society.

Methods: A cross-sectional study was conducted through an online survey in the third week of August 2020. Purposive and random sampling was used to select the respondents. People with a minimum age of 18 years and residing in Indonesia were allowed to participate in this study. The survey was conducted with an online questionnaire that spread on several platforms such as WhatsApp, Instagram and Facebook by distributing the link and continuous chain messages on that platform. Data were analysed using descriptive, chi-square and logistic regression test.

Results: A total of 816 respondents were included in this study. In general, public knowledge about COVID-19 was sufficient, but some topic areas were still low. Most people had a positive attitude about the COVID-19, but they provided a negative response to government policies. Most of the community has taken preventive measures for COVID-19. However, some behaviours received a low percentage. Information about how to prevent COVID-19 was the most wanted information during this pandemic. Social media was a favourite source of information, with the most popular type of visualisation was a table containing numbers. Age and education were significantly associated with knowledge. Some attitudes were affected by age and occupation scope. Gender and health insurance ownership significantly associated with preventive measures.

Conclusion: This research highlights the importance of providing valid, effective, efficient, and continuous information to the public through appropriate channels to increase understanding about COVID-19 precautions.

Keywords: COVID-19, KAP, information needs, information-seeking behaviour

\section{Introduction}

The occurrence of the coronavirus disease 2019 (COVID-19) in Wuhan, China emerged as a rude shock to the entire globe. ${ }^{1}$ This incident was accompanied by rapid transmission and spread all around the world. A total of 215 countries were reported to have been affected by COVID-19 by August 22, 2020, with over 23 million human infections, 807,618 deaths, and more than 15 million recoveries. $^{2,3}$ With limited vaccine to date, the pandemic continues to claim ever more victims. 
The first two cases in Indonesia were confirmed in March $2020^{4}$ and rapidly spread throughout the 34 provinces in this country. About 151,000 sufferers and a mortality rate above 6,000 were recorded as of August 22, 2020. ${ }^{5,6}$ The government, therefore, has exerted numerous efforts towards the COVID-19 pandemic response, including a national budgeting policy, the documentation as a health emergency, along with large-scale social restrictions. ${ }^{7}$ A massive health campaign was created to educate the society about these regulations, including the preventive measures, and also to encourage compliance with the national precautionary guidelines by all parties. ${ }^{8}$

The Indonesian government imposed social distancing rules and implemented comprehensive social restrictions in the 18 selected provinces such as Jakarta and Makasar ${ }^{9}$ rather than a lockdown to alleviate the economic deterioration resulting from the COVID-19 pandemic. $^{10,11}$ These regulations were intended to terminate the spread of COVID-19 by reducing contact amongst individuals. To reinforce these directives, the government limited all public activities and shut all schools down, restricted religious gatherings and public events, as well as facilities, ${ }^{10,12}$ including public transportation to avoid the generation of new cases theoretically triggered by crowds. The government closed workplaces but encouraged the continuation of productive activities. ${ }^{13}$ However, the effectiveness of these interventions is not known. The government of Indonesia has changed its level of intervention to focus prevention of COVID-19 transmission through individual prevention efforts, promulgated by the president of Indonesia's invitation of citizens to enter a new era of living with coronavirus on May 16, $2020 .^{3}$

Considering the transmission of COVID-19 is possible from person to person, the World Health Organization (WHO) stipulated the disease prohibition as a collective responsibility. Also, for universal protection, some practices were to be implemented including wearing mask, frequent washing hands, coughing and sneezing in the elbow, inhibiting public meetings, evading congested spaces, maintaining distances with other people, as well as cleaning and sanitising objects and surfaces. ${ }^{14,15}$ These behaviours are required by the government of Indonesia to help prevent viral transmission. ${ }^{13,16}$ The participation of every individual was required to accomplish the COVID19 control program initiated by the government adequately. ${ }^{8}$ A previous study revealed that societal conformity between the proposed regulations, along with a readiness to tackle the disease was influenced by the possession of knowledge, attitudes, and practices (KAP). ${ }^{17}$ $\mathrm{KAP}$ is a useful tool to assist in plan development, implementation, advocacy, communication and social mobilisation of the health program. ${ }^{18}$ In this case, KAP is essential for health authorities in adjusting COVID-19 prevention measures in the community.

COVID-19 is considered as a newly emerging disease. ${ }^{19-21}$ Recently, the US Food and Drug approved Remdesivir as a substance for COVID-19 treatment in the hospital setting. ${ }^{22}$ This good news does not mean that awareness about transmission of the disease is unnecessary anymore. A study revealed the importance of nonpharmaceutical interventions (NPIs) on reducing the reproduction number of COVID-19 virus ${ }^{23}$ but may limit data in Indonesia about it. Understanding KAP is essential to identify and overcome false rumours about a disease that may negatively influence community prevention behaviour, including NPI. ${ }^{7}$ To rapidly understand COVID-19 $\mathrm{KAP}$ as well as the information needs and seeking behaviours in Indonesia, we surveyed using several of the most popular platforms: WhatsApp, Facebook, and Instagram. ${ }^{24}$ This research contributed to strengthening risk communication effort by related authorities on providing COVID19 information needed and to which group the advocation should be targeted.

\section{Materials and Methods Study Design}

A cross-sectional study was used to assess KAP as well as the information needs during the COVID-19 pandemic in Indonesia. Subjects were recruited by an online survey between 13 and 20 August 2020. Respondents were invited through random sampling. Eligibility requirements were age 18 years or older and residence in Indonesia. Interested respondents returned signed consent forms by pressing the button "agree to participate" and were fulfilling the questionnaire.

\section{Study Instruments}

The questionnaire consisted of 36 items categorised into five sections: 1) socio-demographic data of respondents (name -optional-, sex, age, marital status, education, occupation, city of residence, salary estimation, health insurance ownership, and phone number), 2) COVID-19 knowledge that presented in "Yes/No" question - including (general symptoms, transmission modes, and 
preventive measures), 3) related attitudes using five Likert scales (how the virus was to be overcome and people perception about Indonesia's situation), 4) practices that posted in "Yes/No" question (protective activities: face mask and hand sanitiser use, hand washing, exercise routines, advancements in the food supply, maintaining social distance and where to seek more information), 5) information needs (the type of material desired, source of this information, and the favourite data visualisation preferred). These KAP questions were adapted in part from previous research, ${ }^{17}$ then we added queries related to respondents' information needs. The poll was executed in Bahasa Indonesia and translated into English during manuscript writing. To help improve question validity, questions were kept short and simple, pre-tested via expert review, and further pre-tested in a similar respondent group - similar to the anticipated respondent.

\section{Data Collection Procedure}

A Google Form link was circulated by networks and colleagues through numerous WhatsApp private messages, groups and other social media platforms (Facebook and Instagram) during the research period. To maintain the participant validity, we limited each account to only one response based on their email. At the end of the survey, the link was closed, the data then downloaded and checked for data completeness. If there was any vague answer, we clarified the response with the participant via WhatsApp or telephone. Responses from persons under 18 years of age, residing outside Indonesia, or unwilling to sign a consent form were not included in the analysis.

\section{Statistical Analysis}

The evaluation was performed by employing the Statistical Package for Social Sciences (SPSS) version 24.0 (IBM, Armonk, NY, USA). The socio-demographic data and information needs of the respondents were analysed descriptively. On knowledge, questions were scored with one and zero for the correct and wrong answers, respectively. Also, points of one and zero were allocated to signify agreement and disagreement, respectively, for the attitude category. Finally, the practice questions were graded from zero to two, with the highest value representing the best practice. A total score was calculated for each correct, positive and good answer for $\mathrm{K}, \mathrm{A}$ and $\mathrm{P}$ - respectively. The maximum total scores for knowledge, attitude, and practice were 14,3 , and 34 , respectively.

Logistic regression test was applied to see the association between knowledge and practice category and sociodemographic respondent. Knowledge and practice were divided into two groups - poor and good - less than the mean score categorised as poor and vice versa. Significance was determined at 5\% level ( $P$-value $\leq 0.05)$. The attitude was analysed using chi-square test and last the information needs and information-seeking behaviour was presented descriptively.

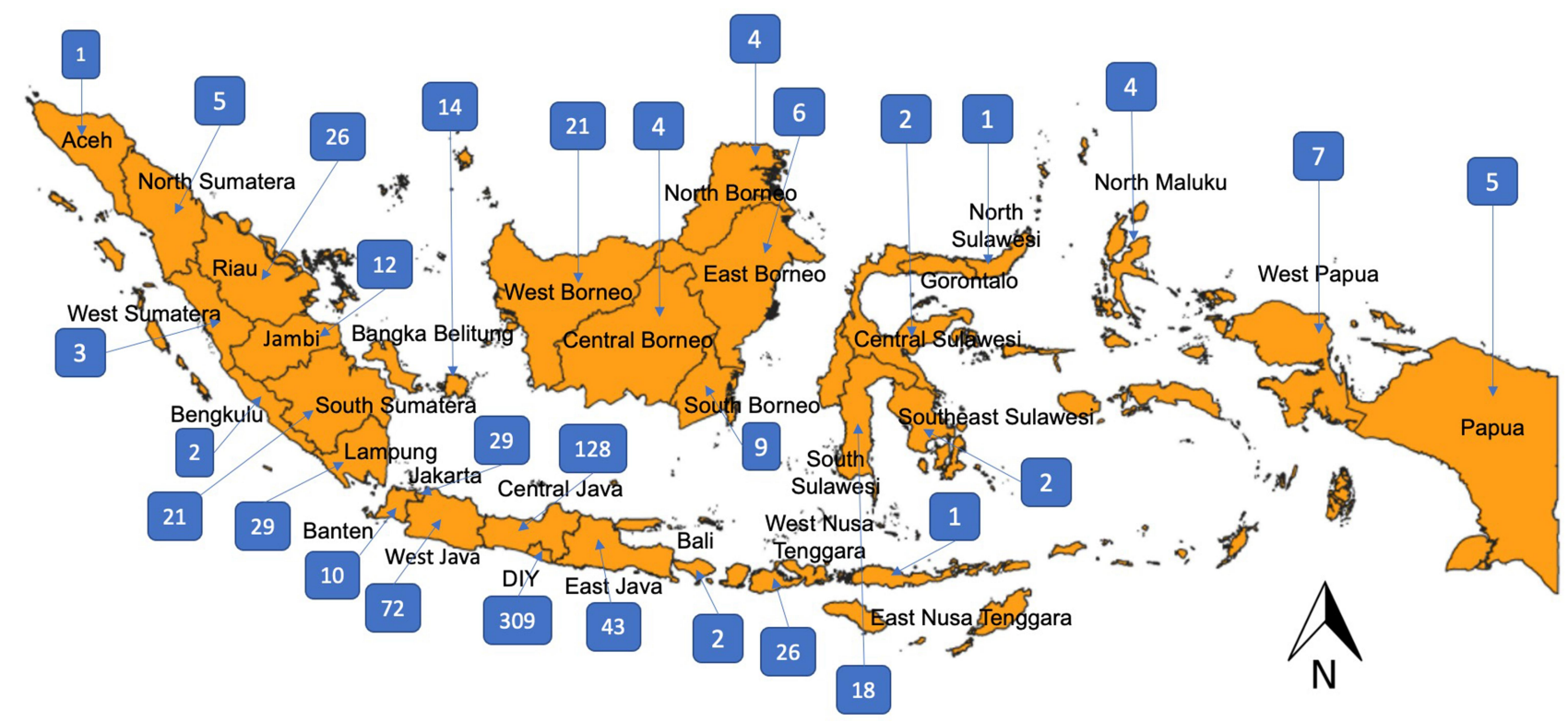

Figure I Participant number and the distribution by the province in Indonesia. 


\section{Ethical Considerations}

The study was approved by the Ethical Review Board of Ahmad Dahlan University, Yogyakarta, Indonesia (ethical approval code: 012008029).

\section{Results}

\section{Socio-Demographic Characteristics}

This study received a total of 858 responses during the online survey, 42 of them were excluded because aged less than 18 years (37), not able to participate (2), and living overseas (3). Therefore, only 816 responses were considered eligible in this study. Figure 1 shows the respondents distribution, spread across 31 out of 34 provinces in Indonesia.

The socio-demographic of respondents are presented in Table 1. Respondent comprised mainly of females (73\%), between 18 and 29 years of age (56.9\%). Furthermore, more than half of the participants were single or had never been married (51.6\%). Also, 57\% of the participants were graduates from higher education, $40.1 \%$ were unemployed. Regarding salary, more than $40 \%$ of respondents reported they were not paid because they were not working anymore. Over half of the participants $(55.8 \%)$ reported having health insurance.

\section{Knowledge About COVID-19}

The information in Table 2 shows over $70 \%$ of respondents correctly answered questions related to COVID-19 general symptoms, transmission modes, and prevention measures. In contrast, only $51.3 \%$ correctly answered about the common cold symptoms consisting of nasal congestion, runny nose, and sneezing are less common in people infected with COVID-19 virus - and only 40\% correctly answered the COVID-19 virus spreads through the air.

Furthermore, among the respondent's socio-demographic features, only age groups and education had a significant association with knowledge of COVID-19. Having an age of more than 50 years was associated with 0.59 - fold higher odds of good knowledge towards COVID-19 compare to people aged $18-29$ years $(P<0.05)$. Respondent graduated from higher education associated with 1.98 - fold higher odds to have good knowledge about COVID-19 than people hold senior high school education $(P<0.05)$. This information is shown in Table 3.
Table I Socio-Demographic Characteristics of Respondents

\begin{tabular}{|c|c|c|}
\hline Characteristics & Number $(\mathbf{N}=8 \mid 6)$ & Percentage (\%) \\
\hline \multicolumn{3}{|l|}{ Gender } \\
\hline Male & 220 & 27.0 \\
\hline Female & 596 & 73.0 \\
\hline \multicolumn{3}{|l|}{ Age group } \\
\hline $18-29$ & 464 & 56.9 \\
\hline $30-49$ & 315 & 38.6 \\
\hline$\geq 50$ & 37 & 4.5 \\
\hline \multicolumn{3}{|l|}{ Marital status } \\
\hline Never married & 421 & 51.6 \\
\hline Ever married & 395 & 48.4 \\
\hline \multicolumn{3}{|l|}{ Education } \\
\hline Senior high school & 270 & 33.1 \\
\hline Diploma & 81 & 9.9 \\
\hline Higher education & 465 & 57.0 \\
\hline \multicolumn{3}{|l|}{ Occupation scope } \\
\hline Unemployed & 327 & 40.1 \\
\hline Student & 46 & 5.6 \\
\hline Government sector & 209 & 25.6 \\
\hline Private sector & 179 & 21.9 \\
\hline Self-employed & 53 & 6.5 \\
\hline Other (Retiree) & 2 & 0.2 \\
\hline \multicolumn{3}{|c|}{ Salary range (million IDR) } \\
\hline Not paid & 377 & 46.2 \\
\hline$<1$ & 32 & 3.9 \\
\hline $1-3$ & 174 & 21.3 \\
\hline$>3-5$ & 149 & 18.3 \\
\hline$>5$ & 84 & 10.3 \\
\hline \multicolumn{3}{|c|}{ Health insurance ownership } \\
\hline Yes & 455 & 55.8 \\
\hline No & 361 & 44.2 \\
\hline
\end{tabular}

\section{Attitude Regarding COVID-19}

Most respondents (95.5\%) agreed that COVID-19 might be controlled. Most ( $80.8 \%$ ) also believed Indonesia might to win against this virus. However, only $48.7 \%$ of respondents agreed that the Indonesian government handled COVID-19 well. Answers to how well the government handled COVID-19 were positively associated with age groups (Figure 2 and Table 4). 
Table 2 Participant Knowledge About COVID-19

\begin{tabular}{|c|c|c|}
\hline Questions & $\begin{array}{l}\text { True } \\
\mathbf{N}(\%)\end{array}$ & $\begin{array}{l}\text { False } \\
\text { N (\%) }\end{array}$ \\
\hline $\begin{array}{l}\text { - The main symptoms of an individual infected } \\
\text { with COVID-19 include fever, feeling of } \\
\text { tiredness, dry cough, and body aches }\end{array}$ & $\begin{array}{l}747 \\
(91.5)\end{array}$ & $69(8.5)$ \\
\hline $\begin{array}{l}\text { - The common cold symptoms consisting of } \\
\text { nasal congestion, runny nose, and sneezing, } \\
\text { are less common in people infected with } \\
\text { COVID-19. }\end{array}$ & $\begin{array}{l}419 \\
(51.3)\end{array}$ & $\begin{array}{l}397 \\
(48.7)\end{array}$ \\
\hline $\begin{array}{l}\text { - There is currently no effective cure for } \\
\text { COVID-19, but early detection and suppor- } \\
\text { tive treatment can help most patients } \\
\text { recover from infection. }\end{array}$ & $\begin{array}{l}804 \\
(98.5)\end{array}$ & $12(1.5)$ \\
\hline $\begin{array}{l}\text { - Not everyone infected with COVID-I9 } \\
\text { develops severely. This only occurs in chil- } \\
\text { dren, the elderly, and/or people with chronic } \\
\text { diseases. }\end{array}$ & $\begin{array}{l}670 \\
(82.1)\end{array}$ & $\begin{array}{l}146 \\
(17.9)\end{array}$ \\
\hline $\begin{array}{l}\text { - Eating or touching wild animals will cause } \\
\text { transmission of the COVID-19 }\end{array}$ & $\begin{array}{l}228 \\
(27.9)\end{array}$ & $\begin{array}{l}588 \\
(72.1)\end{array}$ \\
\hline $\begin{array}{l}\text { - People with COVID-19 cannot transfer the } \\
\text { virus to others if they do not have a fever }\end{array}$ & $56(6.9)$ & $\begin{array}{l}760 \\
(93.1)\end{array}$ \\
\hline $\begin{array}{l}\text { - The COVID-19spreads through the respira- } \\
\text { tory droplets of an infected person }\end{array}$ & $\begin{array}{l}764 \\
(93.6)\end{array}$ & $52(6.4)$ \\
\hline - The COVID-19 spreads through the air & $\begin{array}{l}490 \\
(60.0)\end{array}$ & $\begin{array}{l}326 \\
(40.0)\end{array}$ \\
\hline $\begin{array}{l}\text { - People can use masks to prevent COVID-I9 } \\
\text { infection }\end{array}$ & $\begin{array}{l}809 \\
(99.1)\end{array}$ & $7(0.9)$ \\
\hline $\begin{array}{l}\text { - One of the preventions against COVID-19 is } \\
\text { using hand sanitiser or washing hands with } \\
\text { soap using running water }\end{array}$ & $\begin{array}{l}816 \\
(100.0)\end{array}$ & 0 \\
\hline $\begin{array}{l}\text { - Children and young people do not require to } \\
\text { take precautions for COVID-19 infection }\end{array}$ & $19(2.3)$ & $\begin{array}{l}797 \\
(97.7)\end{array}$ \\
\hline $\begin{array}{l}\text { - To prevent COVID-19 infection, we must } \\
\text { avoid going to crowded places and avoid } \\
\text { using public transportation }\end{array}$ & $\begin{array}{l}794 \\
(97.3)\end{array}$ & $22(2.7)$ \\
\hline $\begin{array}{l}\text { - Isolation and treatment of people infected } \\
\text { with COVID-19 is an effective way to } \\
\text { reduce the virus's spread }\end{array}$ & $\begin{array}{l}808 \\
(99.0)\end{array}$ & $8(1.0)$ \\
\hline $\begin{array}{l}\text { - People who come into contact with some- } \\
\text { one infected with COVID-19 must be } \\
\text { immediately isolated in a particular place, } \\
\text { generally an isolation period of } 14 \text { days }\end{array}$ & $\begin{array}{l}809 \\
(99.1)\end{array}$ & $7(0.9)$ \\
\hline
\end{tabular}

Note: Bold text indicates the correct answer.

\section{Practice Measure Toward COVID-19}

The respondents were assessed using 16 questions presented in Table 5. More than half of the respondents were considered sufficient to have a positive impact on community health and was reported on 10 of the 16 questions. This shows an acceptance of the preventive guidelines mainly covering mouth and nose when sneezing and also washing hands regularly with running water. Furthermore, good practices have been reported by more than $70 \%$ of respondents when asked about the use of hand sanitiser, wear a mask, use of private vehicle, not touching the eyes, nose, and mouth with dirty hands. Meanwhile, a low percentage $(<70 \%)$ was reported for practice-related to nutritional maintenance, shaking of hands and avoidance of crowds.

Insufficient practice measures of less than $60 \%$ occurred in several questions, like monitoring body temperature when feeling unwell (43.1\%), consistent exercise (27\%), maintaining a 1.5 -meter distance from others (57\%), and always staying home $(51.1 \%)$. Meanwhile, with regards to information, only $53.6 \%$ always remain updated, when feeling unwell during the pandemic, $33.6 \%$ reportedly visited the health facilities, about $34 \%$ reported sometimes, and $31.9 \%$ reported never.

Table 6 shows the differences between sociodemographic categories and practice categories. Gender and health insurance ownership significantly associated with the practice measure of the respondent. Being female was associated with 0.41 times higher odds to have good practice about COVID-19 compared with men $(P<0.05)$. A respondent who without health insurance was significantly associated with 1.68 times higher odds of good practice of COVID-19 than people with health insurance $(P<0.05)$.

\section{Information Needs and Information-Seeking Behaviour}

During the COVID-19 pandemic, more than $78 \%$ of the respondents reported seeking information on how to prevent the virus, and about $65 \%$ researched on COVID-19 transmission in Indonesia, cause, treatment and symptoms (Figure S1). Meanwhile, with regards to information type, the majority (65\%) of respondents choose table or number, and almost half selected map as the favourite information visualisation. The respondents reported social media, both 
Table 3 Socio-Demographic Characteristics and Knowledge Score $(N=816)$

\begin{tabular}{|c|c|c|c|c|c|}
\hline \multirow[t]{2}{*}{ Characteristics } & \multirow[t]{2}{*}{ Total Response $(\mathbf{N}=816) \%$} & \multicolumn{2}{|c|}{ Knowledge Category } & \multirow[t]{2}{*}{ OR $(95 \% \mathrm{CI})$} & \multirow[t]{2}{*}{ P-value } \\
\hline & & Poor $(<12.5)$ & Good $(\geq 12.5)$ & & \\
\hline \multicolumn{6}{|l|}{ Gender } \\
\hline Male & $220(27.0)$ & $138(62.7)$ & $82(37.3)$ & Reference & 0.317 \\
\hline Female & $596(73.0)$ & $357(59.8)$ & $239(40.2)$ & $0.83(0.59-1.18)$ & \\
\hline \multicolumn{6}{|l|}{ Age group } \\
\hline $18-29$ & $464(56.9)$ & $306(65.9)$ & $158(34.1)$ & Reference & $0.022^{* *}$ \\
\hline $30-49$ & $315(38.6)$ & I73(29.0) & |42(7|.0) & $0.35(0.15-0.80)$ & \\
\hline$\geq 50$ & $37(4.5)$ & 16(43.2) & $21(56.8)$ & $0.59(0.28-1.22)$ & \\
\hline \multicolumn{6}{|l|}{ Marital status } \\
\hline Never marriage & $42 I(5 I .6)$ & $273(64.8)$ & $148(35.2)$ & Reference & 0.894 \\
\hline Ever marriage & $395(48.4)$ & $222(56.2)$ & $173(43.8)$ & $0.97(0.62-1.51)$ & \\
\hline \multicolumn{6}{|l|}{ Education } \\
\hline Senior high school & $270(33.1)$ & $166(61.5)$ & $104(38.5)$ & Reference & $0.017^{* *}$ \\
\hline Diploma & 81 (9.9) & $35(43.2)$ & $46(56.8)$ & $1.35(0.89-2.06)$ & \\
\hline Higher education & $465(57.0)$ & $294(63.2)$ & $|7|(36.8)$ & $1.98(1.19-3.29)$ & \\
\hline \multicolumn{6}{|l|}{ Occupation scope } \\
\hline Unemployed & $327(40.1)$ & $204(62.4)$ & $123(37.6)$ & $* * *$ & 0.926 \\
\hline Student & $46(5.6)$ & $28(60.9)$ & 18(39.1) & & \\
\hline Government sector & $209(25.6)$ & $116(55.5)$ & $93(44.5)$ & & \\
\hline Private sector & $179(21.9)$ & $116(64.8)$ & $63(35.2)$ & & \\
\hline Self-employed & $53(6.5)$ & $31(58.5)$ & $22(4 I .5)$ & & \\
\hline Other (Retiree)* & $2(0.3)$ & $0(0)$ & $2(100)$ & & \\
\hline \multicolumn{6}{|c|}{ Monthly salary range (million IDR) } \\
\hline None & $377(46.2)$ & $232(61.5)$ & $145(38.5)$ & Reference & 0.775 \\
\hline$<1$ & $32(3.9)$ & $22(68.8)$ & $10(31.2)$ & $0.91(0.56-1.48)$ & \\
\hline $\mathrm{I}-3$ & $174(2 \mid .3)$ & $100(57.5)$ & $74(42.5)$ & $0.66(0.28-1.58)$ & \\
\hline$>3-5$ & $149(18.3)$ & $91(6 I .1)$ & $58(38.9)$ & $1.08(0.64-1.84)$ & \\
\hline$>5$ & $84(10.3)$ & $50(59.5)$ & $34(40.5)$ & $0.93(0.54-1.61)$ & \\
\hline \multicolumn{6}{|c|}{ Health insurance ownership } \\
\hline Yes & $455(55.8)$ & $265(58.2)$ & $190(41.8)$ & Reference & 0.207 \\
\hline No & 361 (44.2) & $230(63.7)$ & $|3|(36.3)$ & $1.22(0.89-1.66)$ & \\
\hline
\end{tabular}

Notes: $*$ Other includes retiree and daily labour. $* *$ Significant at $P<0.05$. $* * *$ Not possible to estimate.

Facebook and Instagram, as the first favourite information source followed by television (Figure 3).

\section{Discussion}

COVID-19 is an extremely aggressive virus due to the ease in the mode of transmission. The primary prevention measures are conducted through behavioural modification on individual hygiene and limiting physical contact among people. Besides, since this disease is new, providing adequate information about the virus, especially preventive measures, it is essential to avoid misinformation in society that could result in incorrect precautionary action. This study helps fill a knowledge gap about COVID-19 Knowledge, Attitude, and Practice (KAP) in Indonesia, which may detect potential barriers to change in social behaviour. ${ }^{25}$ This study specified public knowledge, attitude, and practice about the virus as adequate, with notable weakness in some parts.

The response to this research was generated mostly from females $(73 \%)$. This may be related to men's 


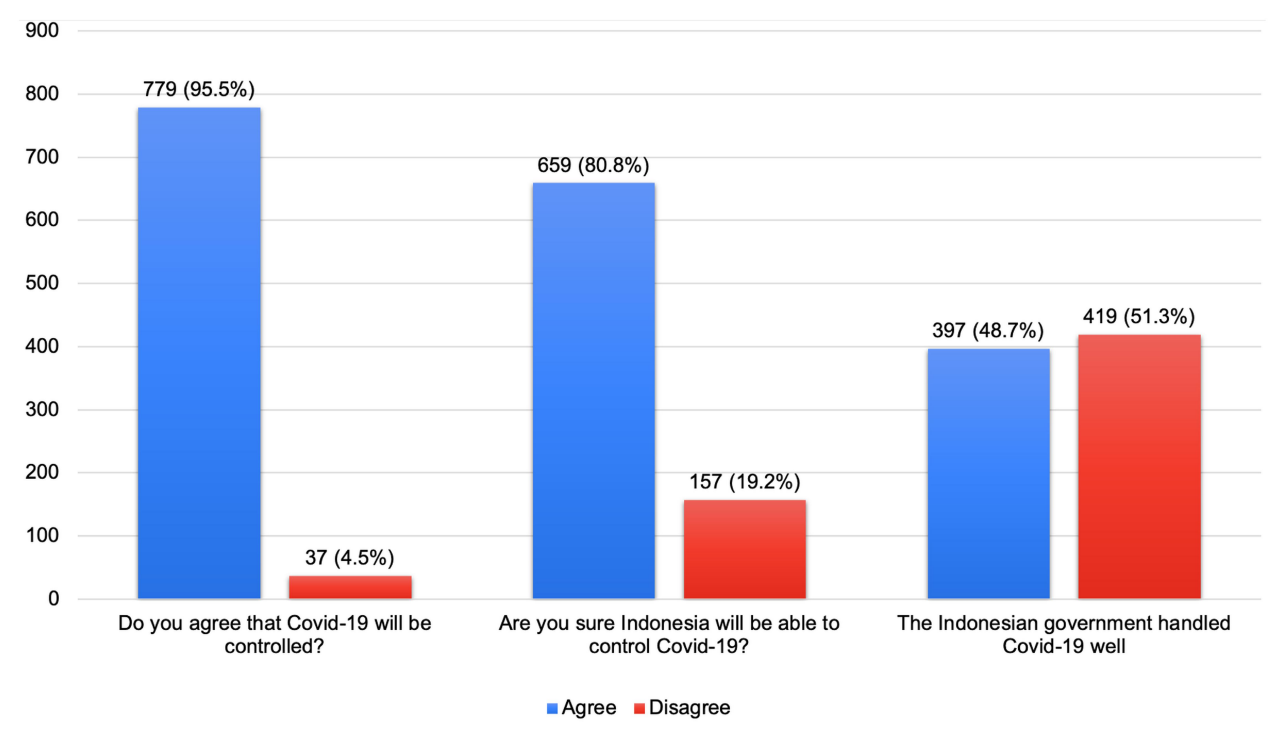

Figure 2 Attitudes towards COVID-19 among participants ( $\mathrm{N}=816)$.

tendency to be more apathetic to a survey than women mainly in this COVID-19 Ipandemic situation, and the same happened in the COVID-19 KAP study in Saudi Arabia in which women mostly responded to the survey. ${ }^{26}$ This is, however, consistent with previous research, proving women to participate more in surveys than men. ${ }^{27,28}$

Knowledge, attitude and practice are interrelated each other. People who have good knowledge expected would be translated into good practice and preventive measure. This research showed the discrepancy between knowledge that does not translate into good attitude and preventive measure - respondent who has good knowledge did not have a proper attitude as well as a preventive measure related to COVID-19. The different result was showed by research in Iran and Bangladesh that the translated of knowledge into attitude and practice seems performed well. $^{29,30}$

This research revealed that persons over age 50 displayed higher knowledge than other age groups. This finding is consistent with research in Malaysia, where people in this group displayed better knowledge about COVID-19. ${ }^{17}$ According to the World Health Organization (WHO), older society is at the highest risk to contract this virus, and more than $95 \%$ of the related death is attributed to this group. ${ }^{31}$ In addition, multiple health conditions, especially chronic disease, biological age, and decreased immunity, are predicted to significantly increase the elderly's susceptibility to infection with this virus. $^{32}$ The massive campaign by various parties/organisations about COVID-19, including information on vulnerable groups, therefore encouraged older people to know more about this disease. This high level of knowledge among older people is coherent with the practice scores across all age groups. Therefore, individuals above 50 years have higher odds to have a good practice measure.

Education is the process learning and gaining knowledge. In our study, people who graduated from higher education more knowledgeable regarding COVID-19. Those with higher education - such as healthcare workers may have a greater need to work during the pandemic, preventing them from fully adhering to preventive measures like staying at home. However, the lower risk by their younger age may offset this risk. ${ }^{33}$ Age and occupation appear to influence public perception of Indonesia's ability to defeat COVID-19 and how well the Indonesian government has handled COVID-19. Although respondents felt Indonesia would be able to control COVID-19, they did not, in general, believe that the Indonesian government had handled the situation well. This is in contrast to reports from Malaysia, where there was higher public support of government action. ${ }^{17}$ It may be because other countries imposed total lockdown, while Indonesia employed policies to protect economic growth and cultural characteristics while also addressing COVID-19, ${ }^{11,34,35}$ which may have been perceived as a lack of direction from the government, and in turn, been blamed for infections and mortality rate. 
Table 4 Socio-Demographic Characteristic and Attitude $(N=816)$

\begin{tabular}{|c|c|c|c|c|c|c|}
\hline \multirow[t]{3}{*}{ Characteristics } & \multicolumn{2}{|c|}{$\begin{array}{l}\text { Do You Agree That COVID-19 } \\
\text { Will Be Overcome? }\end{array}$} & \multicolumn{2}{|c|}{$\begin{array}{l}\text { Are You Sure Indonesia Will Be } \\
\text { Able to Control CoVID-19? }\end{array}$} & \multicolumn{2}{|c|}{$\begin{array}{l}\text { The Indonesian Government } \\
\text { Handled COVID-19 Well. }\end{array}$} \\
\hline & \multicolumn{2}{|l|}{ N (\%) } & \multicolumn{2}{|l|}{$\mathbf{N}(\%)$} & \multicolumn{2}{|l|}{$\mathbf{N}(\%)$} \\
\hline & Disagree & Agree & Disagree & Agree & Disagree & Agree \\
\hline \multicolumn{7}{|l|}{ Gender } \\
\hline Male & $13(5.9)$ & $207(94.1)$ & $42(19.1)$ & I 78 (80.9) & II 5 (52.3) & $105(47.7)$ \\
\hline Female & $24(4.0)$ & $572(95.6)$ & 115 (19.3) & $48 \mid(80.7)$ & $304(5 \mathrm{I} . \mathrm{I})$ & $292(48.9)$ \\
\hline \multicolumn{7}{|l|}{ Age group } \\
\hline $18-29$ & $21(4.5)$ & $443(95.5)$ & I0I (2I.8) & $363(78.2)$ & $26 \mid(56.2)$ & $203(43.8)^{* *}$ \\
\hline $30-49$ & $16(5.1)$ & 299 (94.9) & $52(16.5)$ & $263(83.5)$ & $146(46.4)$ & $169(53.6)$ \\
\hline$\geq 50$ & 0 & $37(100)$ & $4(10.8)$ & $33(89.2)$ & $12(32.4)$ & $25(57.6)$ \\
\hline \multicolumn{7}{|l|}{ Marital status } \\
\hline Never married & $18(4.3)$ & $403(95.7)$ & $85(20.2)$ & $336(79.8)$ & $228(54.2)$ & $193(45.8)$ \\
\hline Ever married & $19(4.8)$ & $376(95.2)$ & $72(18.2)$ & $323(81.8)$ & $191(48.4)$ & $204(5 \mid .6)$ \\
\hline \multicolumn{7}{|l|}{ Education } \\
\hline Senior high school & $10(3.7)$ & $260(96.3)$ & $46(17.0)$ & $224(83.0)$ & $129(47.8)$ & $|4|(52.2)$ \\
\hline Diploma & $4(4.9)$ & 77 (95.I) & $17(2 \mid .0)$ & $64(79.0)$ & $36(44.4)$ & $45(55.6)$ \\
\hline Higher education & $23(2.9)$ & $442(97.1)$ & $94(20.2)$ & $37 \mid(79.8)$ & $254(54.6)$ & $211(45.4)$ \\
\hline \multicolumn{7}{|l|}{ Occupation scope } \\
\hline Unemployed & II (3.4) & $316(96.6)^{* *}$ & $58(17.7)$ & $269(82.3)^{* *}$ & $168(5 \mid .4)$ & $159(48.6)$ \\
\hline Student & $2(4.3)$ & $44(95.7)$ & $12(26.1)$ & 34 (73.9) & $23(50.0)$ & $23(50.0)$ \\
\hline Government sector & $4(1.9)$ & $205(98.1)$ & $29(13.9)$ & $180(86.1)$ & $93(44.5)$ & $116(55.5)$ \\
\hline Private sector & $17(9.5)$ & $162(90.5)$ & $50(27.9)$ & $129(72.1)$ & $109(60.9)$ & $70(39.1)$ \\
\hline Self employed & $3(5.7)$ & $50(94.3)$ & $8(15.1)$ & $45(84.9)$ & $25(47.2)$ & $28(52.8)$ \\
\hline Other (Retiree)* & 0 & $2(100)$ & 0 & $2(100)$ & I (50.0) & I (50.0) \\
\hline \multicolumn{7}{|c|}{ Monthly salary range (million IDR) } \\
\hline None & $12(3.2)$ & $365(96.8)$ & $71(18.8)$ & $306(81.2)$ & $194(5 \mid .5)$ & $183(48.5)$ \\
\hline$<1$ & I (3.1) & $31(96.9)$ & $6(18.8)$ & $26(81.2)$ & $17(53.1)$ & $15(46.9)$ \\
\hline $1-3$ & $13(7.5)$ & $161(92.5)$ & $29(16.7)$ & $145(83.3)$ & $85(48.9)$ & $89(5 I .1)$ \\
\hline$>3-5$ & $8(5.4)$ & I4I (94.6) & $27(18.1)$ & $122(81.9)$ & $76(51.0)$ & $73(49.0)$ \\
\hline$>5$ & $3(3.6)$ & 81 (96.4) & $24(28.6)$ & 60 (7I.4) & $47(56.0)$ & $37(44.0)$ \\
\hline \multicolumn{7}{|c|}{ Health insurance ownership } \\
\hline Yes & $17(3.8)$ & $438(96.2)$ & $90(19.8)$ & $365(80.2)$ & $247(54.3)$ & $208(45.7)$ \\
\hline No & $20(5.5)$ & $34 I$ (94.5) & $67(18.6)$ & $294(81.4)$ & I 72 (47.6) & $189(52.4)$ \\
\hline
\end{tabular}

Notes: *Other includes retiree and daily labour. **Significant at $P<0.05$.

In this research, respondents reported their compliance with many precautionary measures, including, putting on masks, the use of hand sanitiser, proper handwashing practices, physical distancing and avoidance of crowd. However, respondents only sometimes practice regular exercise or visits to the health facilities for assistance.
Engaging in physical activities was not routine before COVID-19, and was made more challenging by the pandemic because sports facilities and fitness centres were closed. A previous study proved relatively low walk time practice by Indonesians compared to residents in other countries. $^{36}$ Poor practice in visiting health facilities 
Table 5 Participant Practice Response Related COVID-19 $(\mathrm{N}=816)$

\begin{tabular}{|c|c|c|c|}
\hline \multirow[t]{2}{*}{ Statements } & Always & Sometimes & Never \\
\hline & $\mathbf{N}(\%)$ & $\mathbf{N}(\%)$ & $\mathbf{N}(\%)$ \\
\hline $\begin{array}{l}\text { - I cover my mouth and nose } \\
\text { when I cough or sneeze }\end{array}$ & $\begin{array}{l}727 \\
(89.1)\end{array}$ & $84(10.3)$ & $5(0.6)$ \\
\hline $\begin{array}{l}\text { - I wash my hands with soap } \\
\text { from running water many } \\
\text { times a day }\end{array}$ & $\begin{array}{l}694 \\
(85.0)\end{array}$ & $|2|(\mid 4.8)$ & $\mathrm{I}(0.1)$ \\
\hline $\begin{array}{l}\text { - I always monitor my tem- } \\
\text { perature when I do not feel } \\
\text { well }\end{array}$ & $\begin{array}{l}352 \\
(43.1)\end{array}$ & $340(41.7)$ & $\begin{array}{l}124 \\
(15.2)\end{array}$ \\
\hline $\begin{array}{l}\text { - I maintain my nutritional bal- } \\
\text { ance by eating lots of vita- } \\
\text { mins and fruit }\end{array}$ & $\begin{array}{l}557 \\
(68.3)\end{array}$ & $257(31.5)$ & $2(0.2)$ \\
\hline - I exercise regularly & $\begin{array}{l}220 \\
(27.0)\end{array}$ & $546(66.9)$ & $\begin{array}{l}50 \\
(6.1)\end{array}$ \\
\hline - I carry hand sanitiser with me & $\begin{array}{l}603 \\
(73.9)\end{array}$ & $179(21.9)$ & $\begin{array}{l}34 \\
(4.2)\end{array}$ \\
\hline - I use a hand sanitiser & $\begin{array}{l}578 \\
(70.8)\end{array}$ & $224(27.5)$ & $\begin{array}{l}14 \\
(1.7)\end{array}$ \\
\hline $\begin{array}{l}\text { - I wear a mask when I go out } \\
\text { of the house }\end{array}$ & $\begin{array}{l}713 \\
(87.4)\end{array}$ & $103(12.6)$ & 0 \\
\hline - I travel using a private vehicle & $\begin{array}{l}723 \\
(88.6)\end{array}$ & $83(10.2)$ & $\begin{array}{l}10 \\
(1.2)\end{array}$ \\
\hline $\begin{array}{l}\text { - I keep a safe distance from } \\
\text { other people, at least } 1.5 \\
\text { meters }\end{array}$ & $\begin{array}{l}465 \\
(57.0)\end{array}$ & $346(42.4)$ & $5(0.6)$ \\
\hline $\begin{array}{l}\text { - I choose to stay at home dur- } \\
\text { ing this pandemic }\end{array}$ & $\begin{array}{l}417 \\
(5 I . I)\end{array}$ & $384(47.1)$ & $\begin{array}{l}15 \\
(1.8)\end{array}$ \\
\hline $\begin{array}{l}\text { - I avoid touching my eyes, } \\
\text { nose, and mouth when my } \\
\text { hands are dirty }\end{array}$ & $\begin{array}{l}647 \\
(79.3)\end{array}$ & $168(20.6)$ & $\mathrm{I}(0 . \mathrm{I})$ \\
\hline - I tried to avoid the crowd & $\begin{array}{l}556 \\
(68.1)\end{array}$ & $256(31.4)$ & $4(0.5)$ \\
\hline - I avoid shaking hands & $\begin{array}{l}557 \\
(68.3)\end{array}$ & $252(30.9)$ & $7(0.9)$ \\
\hline $\begin{array}{l}\text { - I always update information } \\
\text { related to COVID-19 }\end{array}$ & $\begin{array}{l}437 \\
(53.6)\end{array}$ & $362(44.4)$ & $\begin{array}{l}17 \\
(2.1)\end{array}$ \\
\hline $\begin{array}{l}\text { - I visited a health facility when } \\
\text { I felt unwell during the } \\
\text { COVID-I9 pandemic }\end{array}$ & $\begin{array}{l}274 \\
(33.6)\end{array}$ & $282(34.6)$ & $\begin{array}{l}260 \\
(31.9)\end{array}$ \\
\hline
\end{tabular}

seems to be related to the health authority's recommendation that people are not encouraged to visit health facilities except in an emergency during the COVID-19 pandemic. ${ }^{37,38}$ Fortunately, this behaviour may be beneficial during COVID-19, as health facilities may be transmission hubs.

The socio-demographic versus practice score test shows gender and health insurance ownership as the significant determinant for respondent good practice towards COVID19. Females have a better possibility to have a good practice score than men. This result is, consistent with studies in Iran. ${ }^{29}$ Women may have a greater practice to gain COVID19 knowledge because they tend to be the primary caregivers of family members with COVID-19. ${ }^{39,40}$ Women may also seek a greater understanding of COVID-19 to overcome the greater sensitivity to danger and attendant stress reported in women than men. ${ }^{41}$ Therefore, this group is always looking for information and knowledge about COVID-19 to overcome anxiety. This may be because the female is more concerned with surrounding individuals, in turn, leading families to adhere to health protocols when outside the home strictly. This addresses the WHO acknowledgement that COVID-19 prevention is dependent on collective solidarity, and humans are required to protect one another. ${ }^{14,31}$

People who do not have health insurance displayed a better preventive measure than those who have health insurance. Living without health insurance may develop an awareness of the respondent because they do not want to be sick then fall into a situation not productive and should pay some money for the medication. A previous study revealed people own private health insurance tend to have a lower risk of developing a chronic disease because they receive a regular source of care. ${ }^{42}$ The ownership of health insurance indeed changes the people preventive care but little change the people health behaviour. ${ }^{43}$ Health insurance offered adequate protection in the current pandemic COVID-19 situation due to uncertainty situation in both the disease and economical. So, for people who do not protect with insurance, do their best to apply the preventive measure to avoid the disease.

The most frequently searched information was the process of COVID-19 prevention. This is understandable because the disease is relatively new. Accordingly, everyone is unfamiliar with proper prevention measures. The 
Table 6 Socio-Demographic Characteristic and Practice Measure $(N=816)$

\begin{tabular}{|c|c|c|c|c|c|}
\hline \multirow[t]{2}{*}{ Characteristics } & \multirow[t]{2}{*}{ Total Response (N = 816) \% } & \multicolumn{2}{|c|}{ Practice Score Category } & \multirow[t]{2}{*}{ OR $(95 \% \mathrm{Cl})$} & \multirow[t]{2}{*}{ P-value } \\
\hline & & Poor $(<23.5)$ & Good ( $\geq 23.5)$ & & \\
\hline \multicolumn{6}{|l|}{ Gender } \\
\hline Male & $220(27.0)$ & $46(21.0)$ & $174(79.0)$ & Reference & $0.00 I^{* *}$ \\
\hline Female & $596(73.0)$ & $67(11.2)$ & $529(88.8)$ & $0.4 I(0.26-0.66)$ & \\
\hline \multicolumn{6}{|l|}{ Age group } \\
\hline $18-29$ & $464(56.9)$ & $73(15.7)$ & $391(84.3)$ & Reference & 0.575 \\
\hline $30-49$ & $315(38.6)$ & 37 (II.7) & $278(88.3)$ & $0.49(0.12-2.00)$ & \\
\hline$\geq 50$ & $37(4.5)$ & $3(8.1)$ & $34(91.9)$ & $0.61(0.16-2.27)$ & \\
\hline \multicolumn{6}{|l|}{ Marital status } \\
\hline Never marriage & $421(51.6)$ & $66(15.7)$ & $355(84.3)$ & Reference & 0.935 \\
\hline Ever marriage & $395(48.4)$ & 47 (II.9) & $348(88.1)$ & $0.97(0.52-1.82)$ & \\
\hline \multicolumn{6}{|l|}{ Education } \\
\hline Senior high school & $270(33.1)$ & $45(16.7)$ & $225(83.3)$ & Reference & 0.707 \\
\hline Diploma & 81 (9.9) & $6(7.4 I)$ & 75 (92.59) & $0.98(0.56-1.70)$ & \\
\hline Higher education & $465(57.0)$ & $62(13.3)$ & $403(86.7)$ & $1.45(0.58-3.62)$ & \\
\hline \multicolumn{6}{|l|}{ Occupation scope } \\
\hline Unemployed & $327(40.1)$ & $51(15.6)$ & $276(84.4)$ & Reference & $0.28 I$ \\
\hline Student & $46(5.6)$ & $5(10.9)$ & $41(89.1)$ & & \\
\hline Government sector & $209(25.6)$ & $18(8.6)$ & 191 (91.4) & $7.79(0.33-180.32)$ & \\
\hline Private sector & $179(21.9)$ & $26(14.5)$ & $153(85.5)$ & $8.10(0.37-177.27)$ & \\
\hline Self-employed & $53(6.5)$ & $12(22.6)$ & $41(77.4)$ & $5.45(0.25-111.88)$ & \\
\hline Other (Retiree)* & $2(0.3)$ & $\mathrm{I}(50)$ & $\mathrm{I}(50)$ & $2.85(0.13-60.87)$ & \\
\hline \multicolumn{6}{|c|}{ Monthly salary range (million IDR) } \\
\hline None & $377(46.2)$ & $57(15.1)$ & $320(84.9)$ & Reference & 0.820 \\
\hline$<1$ & $32(3.9)$ & $7(21.9)$ & $25(78.1)$ & $0.72(0.22-2.36)$ & \\
\hline $\mathrm{I}-3$ & $174(2 \mid .3)$ & $22(12.6)$ & $152(87.4)$ & $1.17(0.50-2.78)$ & \\
\hline$>3-5$ & $149(18.3)$ & $17(1 \mathrm{l} .4)$ & $132(88.6)$ & $1.02(0.43-2.45)$ & \\
\hline$>5$ & $84(10.3)$ & $10(11.9)$ & $74(88.1)$ & $1.68(1.08-2.60)$ & \\
\hline \multicolumn{6}{|c|}{ Health insurance ownership } \\
\hline Yes & $455(55.8)$ & $47(10.3)$ & $408(89.7$ & Reference & $0.019 * *$ \\
\hline No & $361(44.2)$ & $66(18.2)$ & $295(81.8)$ & $1.68(1.08-2.60)$ & \\
\hline
\end{tabular}

Notes: $*$ Other includes retiree and daily labour. $* *$ Significant at $\mathrm{p}<0.05$. $* * *$ Not possible to estimate.

results indicate people's concerns and fears about the infection by updating information related to COVID-19 precautions. Respondents preferred social media (i.e., Facebook and Instagram), followed by television news as information sources. They chose information presented with maps or in tables containing numbers.

The flow of information is swift in the current digital 4.0 era, but there is a risk of misleading information, including health issues. ${ }^{44}$ However, fast and accurate innovation on the public's data requires an opportunity to educate the people about health, including COVID-19 to improve the societies' preventive behaviour. ${ }^{45}$ Therefore, the authorities' role in providing valid, useful, and efficient information is necessary to balance challenges and opportunities as well as to counter misinformation spread in cyberspace, including social media and television. The development and update of information with attractive visualisations are of necessity.

This study has three limitations, therefor the result interpretations should be conducted with care. The first is related to the sample that ran online. However, there have been attempts 


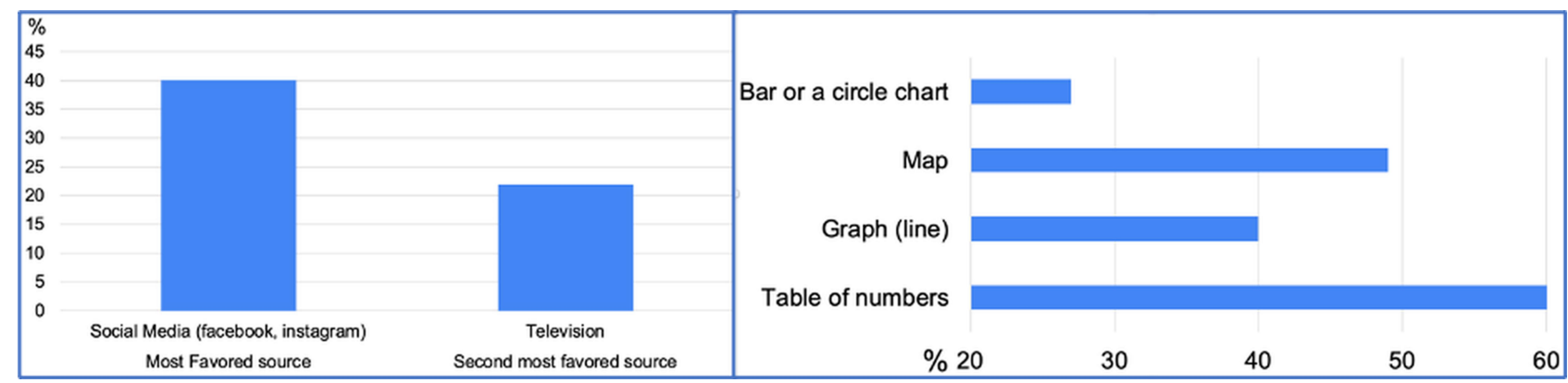

Figure 3 The favourite information source (left) and type visualisation (right) about COVID-19 (N=8I6).

to control bias sampling by establishing inclusion criteria in terms of age and respondent country living. The second is related to data where this research acquired information from the participant's self-reporting. This means the answers are impossible to control, especially on practical questions where ideal observations of the respondents are created. The last limitation is about the respondent's favourite information source; even though they mentioned social media and television as the favourite information source, we did not assess the exact information that comes from which is related to the information credibility. Besides the limitations, this research strength is from the methodology perspective that used a rapid survey to collect the KAP data. This approach may allow the researcher as well as a policy maker to develop disease preventive measures in this current pandemic situation quickly.

\section{Conclusions}

In conclusion, Knowledge, Attitude, Practice, data needs, and information-seeking behaviour about COVID-19 is essential to the formulation of appropriate interventions to control this disease successfully. This study helps fill gaps in COVID-19 KAP in Indonesia and describes the information Indonesians desire, how they prefer information presented, and their selected sources of information. The knowledge, attitude, and prevention measures towards COVID-19 were affected by age, education, work scope, gender and health insurance ownership. This research suggests that health authorities improve the process of messaging and updating the information related to this disease through proper media and target the appropriate population group to increase society's preventive measures. To date, the Indonesia government has primarily relied on television and social media on delivering COVID-19 information updates. It must be continued but needs to be expanded by adjusting the content of the information provided to reach influential groups. Information on preventing COVID-19 must be continuously carried and updated, considering that COVID-19 is still a new disease, and various regulations and research are still developing.

\section{Acknowledgments}

We wish to thank all the participants who contributed to this study.

\section{Funding}

This research was funded by the Ministry of Research and Technology of Indonesia (KEMENRISTEK/BRIN) to finance this research, grant number PDUPT-001/SKPP. TJ/LPPM UAD/VI/2020.

\section{Disclosure}

The authors declare no conflict of interest.

\section{References}

1. Li H, Liu S, Yu X, Tang S, Tang C. Coronavirus disease 2019 (COVID-19): current status and future perspectives. Int J Antimicrob Agents. 2020;55(5):105951. doi:10.1016/j.ijantimicag.2020.105951

2. Worldometers. Coronavirus Cases. Web Page. 2020. Available from: https://www.worldometers.info/coronavirus/. Accessed August 23, 2020.

3. Kurniawan R. VIDEO: the journey of handling covid-19 in Indonesia. CNN TV. 2020. Available from: https://www.cnnindonesia.com/tv/ 20200727191607-407-529505/video-perjalanan-penanganan-covid-19di-indonesia. Accessed August 23, 2020.

4. WHO Indonesia. Coronavirus Disease 2019 (COVID-19) situation report-1. 2020. Available from: https://www.who.int/docs/defaultsource/searo/indonesia/covid19/who-indonesia-situation-report-1.pdf? sfvrsn=6be5b359_0. Accessed August 23, 2020.

5. The Indonesian COVID-19 Task Force. Infografis COVID-19 (22 Agustus 2020). 2020. Available from: https://covid19.go.id/p/berita/ infografis-covid-19-22-agustus-2020. Accessed August 23, 2020.

6. Kurnia D. Complete update on the distribution of positive corona cases in 34 Indonesian Provinces, Friday. Pekanbaru.com. August 21, 2020. Available from: https://fixpekanbaru.pikiran-rakyat.com/nasional/pr41681484/update-lengkap-sebaran-kasus-positif-corona-di-34-provinsiindonesia-jumat-21-agustus-2020?page $=8$. Accessed August 23, 2020.

7. Djalante R, Lassa J, Setiamarga D, et al. Review and analysis of current responses to COVID-19 in Indonesia: period of January to March 2020. Prog Disaster Sci. 2020;6:100091. doi:10.1016/j. pdisas.2020.100091 
8. The Ministry of Health of Indonesia. Guideline of prevention and control the Coronavirus Disease (COVID-19). 2020. Available from: https://covid19.go.id/storage/app/media/Protokol/REV-05_ Pedoman_P2_COVID-19_13_Juli_2020.pdf. Accessed December $16,2020$.

9. Mashabi S. Daftar 18 daerah yang terapkan PSBB, dari Jakarta hingga Makassar. Kompas.com. 2020. Available from: https:// nasional.kompas.com/read/2020/04/20/05534481/daftar-18-daerahyang-terapkan-psbb-dari-jakarta-hingga-makassar?page=all . Accessed October 24, 2020.

10. EKONID News. Govt. to allow large scale social restrictions to prevent the spread of COVID-19. 2020. Available from: https://indone sien.ahk.de/infothek/news/news-details/govt-to-allow-large-scalesocial-restrictions-to-prevent-the-spread-of-covid-19. Accessed August 23, 2020.

11. Andika S, Damhuri E. Why Indonesia does not impose lockdown? Republika Online. March 24, 2020. Available from: https://republika. co.id/berita/q7nbjb440/why-indonesia-does-not-impose-lockdown. Accessed September 1, 2020.

12. Adi GN, Rochman A. Regions close schools, cancel public events because of COVID-19. The Jakarta Post. March 15, 2020. Available from: https://www.thejakartapost.com/news/2020/03/15/regions-close -schools-cancel-public-events-because-of-covid-19.html. Accessed September 1, 2020.

13. EKONID Insight. COVID-19 developments in Indonesia. Web Page. 2020. Available from: https://indonesien.ahk.de/en/infocenter/news/ news-details/covid-19-developments-in-indonesia. Accessed August 31, 2020.

14. WHO Western Pacific. COVID-19 advice - protect yourself and others. Web Page. 2020. Available from: https://www.who.int/wester npacific/emergencies/covid-19/information/transmission-protectivemeasures. Accessed August 23, 2020.

15. CDC. How to protect yourself \& others. Web Page. 2020. Available from: https://www.cdc.gov/coronavirus/2019-ncov/prevent-gettingsick/prevention.html. Accessed August 23, 2020.

16. Loasana NA. COVID-19: health minister issues 'new normal' guidelines for workplaces. The Jakarta Post. May 25, 2020. Available from: https://www.thejakartapost.com/news/2020/05/25/covid-19health-minister-issues-new-normal-guidelines-for-workplaces.html. Accessed August 31, 2020.

17. Azlan AA, Hamzah MR, Sern TJ, Ayub SH, Mohamad E, Tu W-J. Public knowledge, attitudes and practices towards COVID-19: a cross-sectional study in Malaysia. PLoS One. 2020;15(5):1-15. doi:10.1371/journal.pone. 0233668

18. WHO. Advocacy, Communication and Social Mobilization for TB Control: A Guide to Developing Knowledge, Attitude and Practice Surveys. 2008.

19. AlTakarli NS. Emergence of COVID-19 infection: what is known and what is to be expected - narrative review article. Dubai Med J. 2020;3(1):13-18. doi:10.1159/000506678

20. Sanche S, Lin YT, Xu C, Romero-Severson E, Hengartner N, Ke R. High contagiousness and rapid spread of severe acute respiratory syndrome coronavirus 2. Emerg Infect Dis. 2020;26(7):1470-1477. doi:10.3201/eid2607.200282

21. Schröder I. COVID-19: a risk assessment perspective. ACS Chem Health Saf. 2020;27(3):160-169. doi:10.1021/acs.chas.0c00035

22. The US Food and Drug. Coronavirus (COVID-19) update: FDA authorizes drug combination for treatment of COVID-19. 2020. Available from: https://www.fda.gov/news-events/pressannouncements/coronavirus-covid-19-update-fda-authorizes-drugcombination-treatment-covid-19. Accessed November 29, 2020.

23. Bo Y, Guo C, Lin C, et al. Effectiveness of non-pharmaceutical interventions on COVID-19 transmission in 190 countries from 23 January to 13 April 2020. Int J Infect Dis. 2020;102:247-253. doi:10.1016/j.ijid.2020.10.066
24. Green House. Indonesia's social media landscape: an overview. Web Page. 2019. Available from: https://greenhouse.co/blog/indonesiassocial-media-landscape-an-overview/. Accessed September 19, 2020.

25. USAID and SPRING. The KAP survey model (knowledge, attitudes, $\&$ practices) content summary. 2011. Available from: http://www. medecinsdumonde.org/Outils/Nous-contacterURL:http://www.mede cinsdumonde.org/en/actualites/publications/2012/02/20/kap-surveymodel-knowledge-attitude-and-practices. Accessed August 29, 2020.

26. Khaled A, Siddiqua A, Makki S. The knowledge and attitude of the community from the Aseer Region, Saudi Arabia, toward COVID-19 and their precautionary measures against the disease. Risk Manag Healthc Policy. 2020;13:1825-1834. doi:10.2147/RMHP.S271899

27. Singer E, Hoewyk JV, Maher MP. Experiments with incentives in telephone surveys. Public Opin Q. 2000;64(2):171-188. doi:10.1086/317761

28. Curtin R, Presser S, Singer E. The effects of response rate changes on the index of consumer sentiment. Public Opin Q. 2000;64 (4):413-428. doi:10.1086/318638

29. Honarvar B, Lankarani KB, Kharmandar A, et al. Knowledge, attitudes, risk perceptions, and practices of adults toward COVID-19: a population and field-based study from Iran. Int J Public Health. 2020;65(6):731-739. doi:10.1007/s00038-020-01406-2

30. Rahman A, Sathi NJ. Knowledge, attitude, and preventive practices toward COVID-19 among Bangladeshi internet users. Electron J Gen Med. 2020;17:5. doi:10.29333/ejgm/8223

31. WHO-Europe. Statement - older people are at highest risk from COVID-19, but all must act to prevent community spread. Web Page. August 29, 2020. Available from: https://www.euro.who.int/en/ health-topics/health-emergencies/coronavirus-covid-19/statements/state ment-older-people-are-at-highest-risk-from-covid-19,-but-all-must-actto-prevent-community-spread. Accessed August 29, 2020.

32. Begley S. What explains Covid-19's lethality for the elderly? STAT. March 30, 2020. Available from: https://www.statnews.com/2020/03/ 30/what-explains-coronavirus-lethality-for-elderly/. Accessed August 29, 2020.

33. Dunleavy BP. Study: young people at lower risk for COVID-19, can still transmit the virus. UPI. 2020. Available from: https://www.upi. com/Health_News/2020/04/22/Young-people-at-lower-risk-forCOVID-19-can-still-transmit-the-virus/5711587570960/. Accessed August 31, 2020.

34. Sutrisno B. Partial lockdown was the right thing to do, Jokowi says. The Jakarta Post. July 17, 2020. Available from: https://www.theja kartapost.com/news/2020/07/17/partial-covid-19-lockdown-was-theright-thing-to-do-jokowi-says.html. Accessed August 29, 2020.

35. The Jakarta Post. No lockdown for Indonesia, Jokowi insists as COVID-19 cases continue to rise. The Jakarta Post. March 24, 2020. Available from: https://www.thejakartapost.com/news/2020/ 03/24/no-lockdown-for-indonesia-jokowi-insists-as-covid-19-casescontinue-to-rise.html. Accessed August 29, 2020.

36. Wargadiredja AT, Renaldi A. Indonesians walk less than anyone else in the world. This is why. VICE. 2017. Available from: https://www. vice.com/en_asia/article/43d7vw/indonesians-walk-less-than-anyoneelse-in-the-world-this-is-why. Accessed August 29, 2020.

37. Farisa FC. IDI's appeal for communities, doctors, and hospitals to face the covid-19 outbreak. Kompas.com. March 18, 2020.

38. Femina. In the COVID-19 pandemic, should you go to the hospital? Femina. March 2020. Available from: https://www.femina.co.id/ health-diet/di-tengah-pandemi-covid-19-perlukah-memeriksakan-diri -ke-rumah-sakit-. Accessed August 29, 2020.

39. Sulistyawati S, Astuti FD, Umniyati SR, et al. Dengue vector control through community empowerment: lessons learned from a community-based study in Yogyakarta, Indonesia. Int $J$ Environ Res Public Health. 2019;161013. doi:10.3390/ijerph16061013

40. Colfer CJP, Achdiawan R, Roshetko JM, et al. The balance of power in household decision-making: encouraging news on gender in Southern Sulawesi. World Dev. 2015;76:147-164. doi:10.1016/j. worlddev.2015.06.008 
41. Donner NC, Lowry CA. NIH public access. Pflugers Arch. 2013;465 (5):601-626. doi:10.1007/s00424-013-1271-7.Sex

42. Lee M, Park S, Lee K-S. Relationship between morbidity and health behavior in chronic diseases. J Clin Med. 2020;9(1):121. doi: $10.3390 / \mathrm{jcm} 9010121$

43. Jerant A, Fiscella K, Tancredi DJ, Franks P. Health insurance is associated with preventive care but not personal health behaviors. $J$ Am Board Fam Med. 2013;26(6):759-767. doi:10.3122/ jabfm.2013.06.130054
44. Suciu P. COVID-19 misinformation remains difficult to stop on social media. Forbes. 2020. Available from: https://www.forbes.com/sites/ petersuciu/2020/04/17/covid-19-misinformation-remains-difficult-tostop-on-social-media/\#62ef3cdc4819. Accessed August 29, 2020.

45. Liu PL. COVID-19 information seeking on digital media and preventive behaviors: the mediation role of worry. Cyberpsychol Behav Soc Netw. 2020;1-6. doi:10.1089/cyber.2020.0250

\section{Publish your work in this journal}

Risk Management and Healthcare Policy is an international, peerreviewed, open access journal focusing on all aspects of public health, policy, and preventative measures to promote good health and improve morbidity and mortality in the population. The journal welcomes submitted papers covering original research, basic science, clinical \& epidemiological studies, reviews and evaluations, guidelines, expert opinion and commentary, case reports and extended reports. The manuscript management system is completely online and includes a very quick and fair peer-review system, which is all easy to use. Visit http://www.dovepress.com/testimonials.php to read real quotes from published authors.

Submit your manuscript here: https://www.dovepress.com/risk-management-and-healthcare-policy-journal 